\title{
The porential for monitoring air parameters in the determination of carbon monoxide sources in light of research projects
}

\begin{abstract}
First, a recapitulation is provided of monitoring systems, based on electronic solutions which ensure the reliability of the requisite speed and measurements while intrinsically safe. Subsequently, examples of measurements of the carbon monoxide concentrations emitted by different sources are presented. In the context of the different characteristics of changes in carbon monoxide concentration, the problem of the identification of carbon monoxide source generated during high energy rock burst is discussed. To alt a better understanding of the issue, the conditions of mine development work in areas threatened by bumping hazards as well as mining procedures in seams in this type of hard coal deposit, is presented. Finally, the results of comparative tests of changes in carbon monoxide concentrations and conclusions are given.
\end{abstract}

Key words: hazards, monitoring systems, electronics, carbon monoxide sources

\section{INTRODUCTION}

In the Polish mining industry, the average depth of mined hard coal seams is greater year by year by about 8 meters. As a result, the mining and geological conditions during development and mining work are becoming increasingly difficult. This process usually leads to an increase in the intensity of hazards which accompany mining work, such as fires, dust, water, coal dust explosions the presence of methane, bumping, gases rock bursts and other climatic hazards. The better the recognition of those hazards at the design stage, the greater in the potential to prepare prophylactic measures ensuring the safety of mining work. However, the interim control of the parameters characterizing the given hazard is most important as it facilitates an immediate reaction to an approaching hazard.

At present, different types of monitoring systems are used from dispatcher systems decision-making process to alarm communication systems for quicker and automatic announcement about possible dangers or the need to evacuate crews from the danger zone.
However, it should be noted that not all the hazards can be continuously monitored at present and that there is still much to do in this domain.

Only a fraction of the possibilities of monitoring systems in the control and assessment of areological phenomena is presented in the article. Regarding an incident which took place on $5^{\text {th }}$ May 2018, the potential to control carbon monoxide concentrations in the mine air in question together with automatic assessment of the CO source, is presented.

\section{CHARACTERISTICS OF THE MONITORING SYSTEM}

Mine aerometry systems are commonly used for the control and assessment of parameters of air flowing in underground mine workings [1]. They typically consist of an automatic gasometrical system and in the presence of methane hazards - an automatic methanometric system. In the case of bumping hazards, the mine aerometry systems are integrated with micro-seismic and seismic-acoustic monitoring systems. 
Methanometry has always had a protective function, consisting of automatically switching off machines and power supply equipment in areas where the flowing air has over-standard concentrations of methane. The use of such protective measures in classical gasometry dates back to the middle of first decade of twenty first century. This means for example power supply switch off in the case of drop in air flowrate in the longwall panel or face area with methane explosion hazard or in the case of simultaneous door opening in the ventilation damps stabilizing air flow direction and air output as well as in the case of rock burst of energy exceeding that one specified by a mine crew. In the case of the last situation, cutting off the power supply has to eliminate the potential generation of electric sparks with might occur as a result of the power cable breaking, which in turn could lead to a methane explosion.

In underground mines, a telecommunication system [2] adequate for the given type of mining industry is indispensable for the proper processing of information about measured parameters and for its proper use. Telecommunication [3] is the transmission or receiving of information of any nature by wire, radio, optical and electromagnetic systems. Each monitoring system should guarantee the reliability of data measurement transmission and should have the required speed of data processing. The potential to determine the device's uncertainty in terms of device/sensor (uncertainty in the rated conditions), transmission resolution, resolution of recording the measurements result in a repository as well as the recording format $[4,5]$, is important. Besides, in underground mines where a methane and/or coal dust explosion hazard is possible, the communication system should meet the following tougher requirements [6]:

- underground telecommunication systems should be intrinsically or optically safe (feature "description" acc. to PN-EN 60079-28 [7]) and should be able to operate in atmosphere of any methane concentration,

- telecommunication devices as well as cooperating devices used in underground mine workings should have a protection level of enclosures with a minimum of IP54 - due to the humidity as the presence salt and dust,

- the use of a branched out structure of the telecommunication network due the small transverse dimension of roadways (up to few meters) in relation to their longitudinal dimension (up to few kilometres); expanse of the workings.
It is also important to ensure maximum effectiveness of the distribution of electrical and telecommunication earthing (including SUPOgiven the risk posed by the cumulation (in a confined space) of high power electrical grids and devices.

The continuity of the power supply of these devices is an important issue with telecommunication systems. While typical restrictions resulting from:

- planned electrical grid shut down (due to e.g. required repairs),

- periodical tests of switching off the electrical devices required by the gasometry systems,

- the unplanned switching off of the electrical devices caused by the activation of electrical and methane metric protection systems,

do not cause significant problems in assessing hazards level, a break in power supply and/or data transmission - e.g. caused by a methane and/or coal dust explosion or a rock burst - can result in stopping the transmission of information from the area affected by such event. In order to assess what may have happened in this area, we need to use indirect methods based on information acquired from area outside of this zone.

\section{ASSESSMENT \\ OF CARBON MONOXIDE SOURCE BASED ON THE CHARACTERISTICS OF THE CHANGES IN CO CONCENTRATION}

Endogenic fire hazards is a typical hazard in hard coal mines. A carbon monoxide concentration in mine air of above $26 \mathrm{ppm}$ or $\mathrm{CO}$ volumes of over $25 \mathrm{dm}^{3} / \mathrm{min}$ is recognized - if the CO is not generated by means of a technological process - as a fire. In such cases, a fire rescue action should be initiated. The standard methods for monitoring the areological hazards can sometimes result in faulty interpretation of the carbon monoxide source and therefore afire rescue action may be unitiated unnecessarily thus generating unjustified costs.

There are many reasons for the appearance of carbon monoxide levels over and above the standard concentration or/and volume, therefore the rapid identification of the $\mathrm{CO}$ sources is important [8]. That is why tests for the quick, automatic identification of $\mathrm{CO}$ sources were conducted [9] within the 
framework of the European project: Minimising the risk of and reducing the impact of fire and explosion hazard in underground coal mining industry, cofinanced by the Research Fund for Coal and Steel. The development of effective detection procedures for dangerous atmospheres and flammable gases, whilst eliminating the faulty interpretation of increased carbon monoxide concentrations was the main objective of the project (the project was implemented by an international consortium, including the Institute

a)

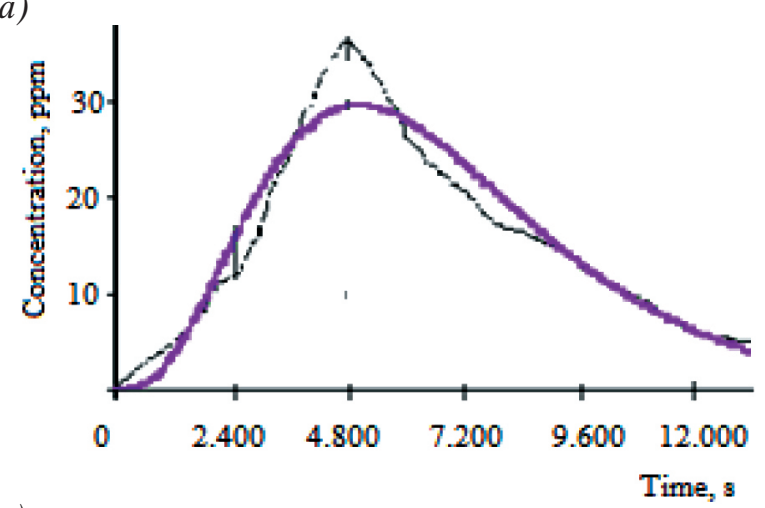

c)

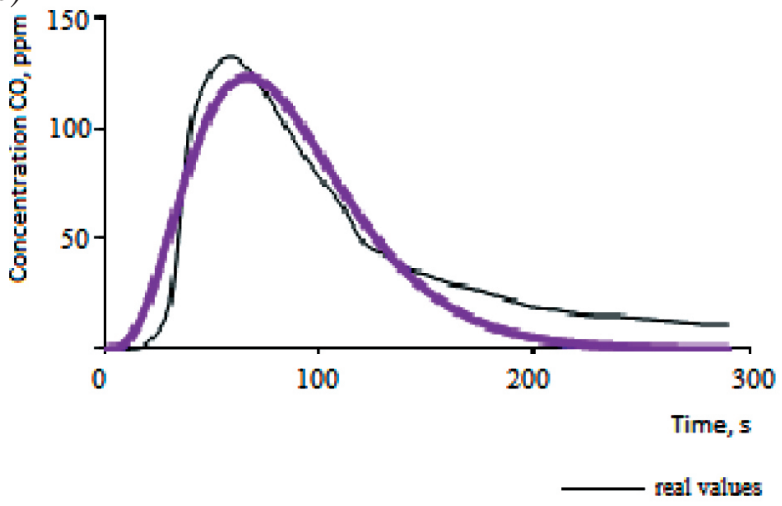

of Innovative Technologies EMAG and the Institute of Mining Technology KOMAG).

The tests conducted enabled the development of model for identifying changes in $\mathrm{CO}$ concentrations depending on of its source type (Fig. 1) as well as development of $\mathrm{CO}$ source identification subsystem cooperating with the standard monitoring systems.

However, it transpires that the identification of the $\mathrm{CO}$ source is far from obvious, as illustrated in the example below.
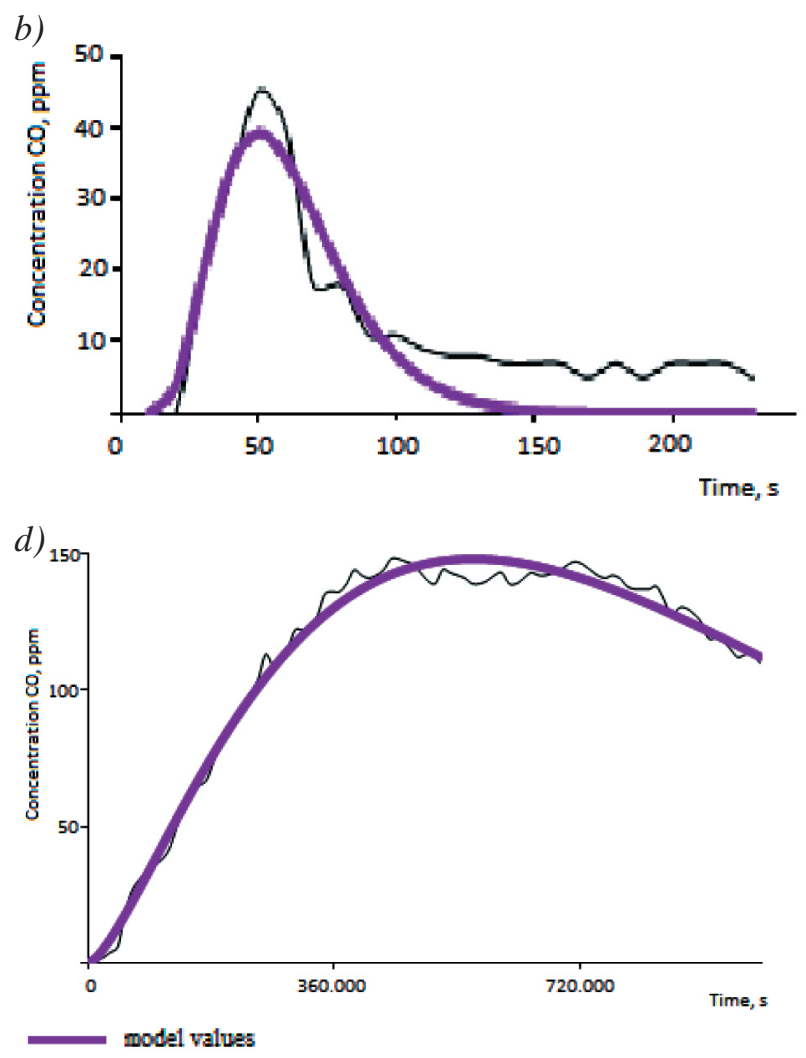

Fig. 1. Models of changes in CO concentration depending on its source: a) results of gas outflow from the gob; b) results of the operation of a diesel machine; c) results of blasting operations d) spontaneous fire [9]

\section{DETERMINATION OF CARBON MONOXIDE EMISSION SOURCES IN THE CASE OF ROCK BURSTS AND BLASTING OPERATIONS - AFEASIBILITY STUDY}

On 5 May 2018 at 10:58 a.m., a high-energy rock burst $\left(E=2.0 \cdot 10^{9} \mathrm{~J}\right)$ occurred. At the beginning the recorded energy was $E=1.9 \cdot 10^{8} \mathrm{~J}-$ Figure 2. About 820 meters of mine roadway sections were affected, in the $\mathrm{H}$ part of the $409 / 4$ seam, from a total length of prepared roadways which amount to $2700 \mathrm{~m}$. The President of the State Mining Authority appointed a special commission to investigate the reasons as well as circumstances of this bump [10].
As a result of the bump, the automatic methane sensors installed in this area, as well as the automatic $\mathrm{CO}$ sensors stopped operating due to break in power supply and transmission of data measurements. Only the sensors which were outside the affected area remained in were operation (Fig. 3).

The operating methane sensors - MM187 and MM123 - recorded a significant increase in methane concentratios (Fig. 4) (exceedance of permissible concentrations marked in red, permissible concentrations marked in green), similarly the CO sensors M712 and M730, recorded increased concentration but witch much lower dynamics (Fig. 5). 


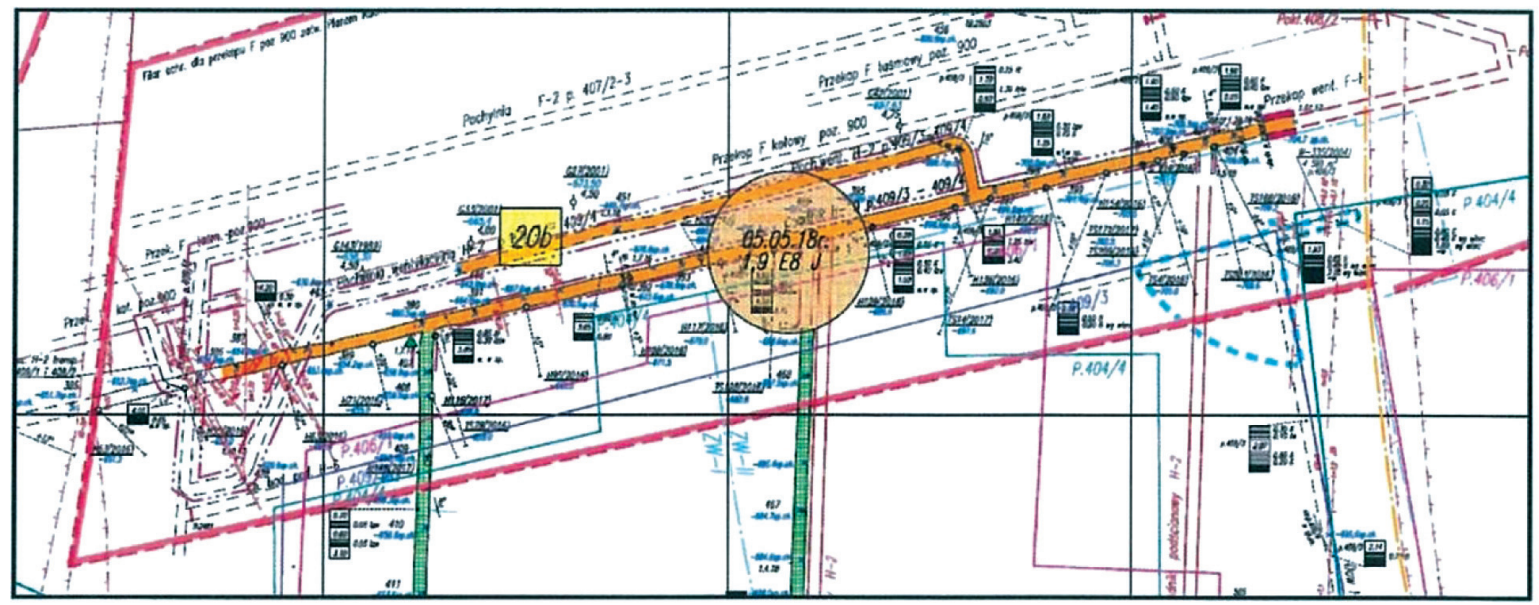

Fig. 2. A fragment of the map of mining headings of 409/4 deck in lot $H$ together with location of the rock burst in the area of mining work [11]

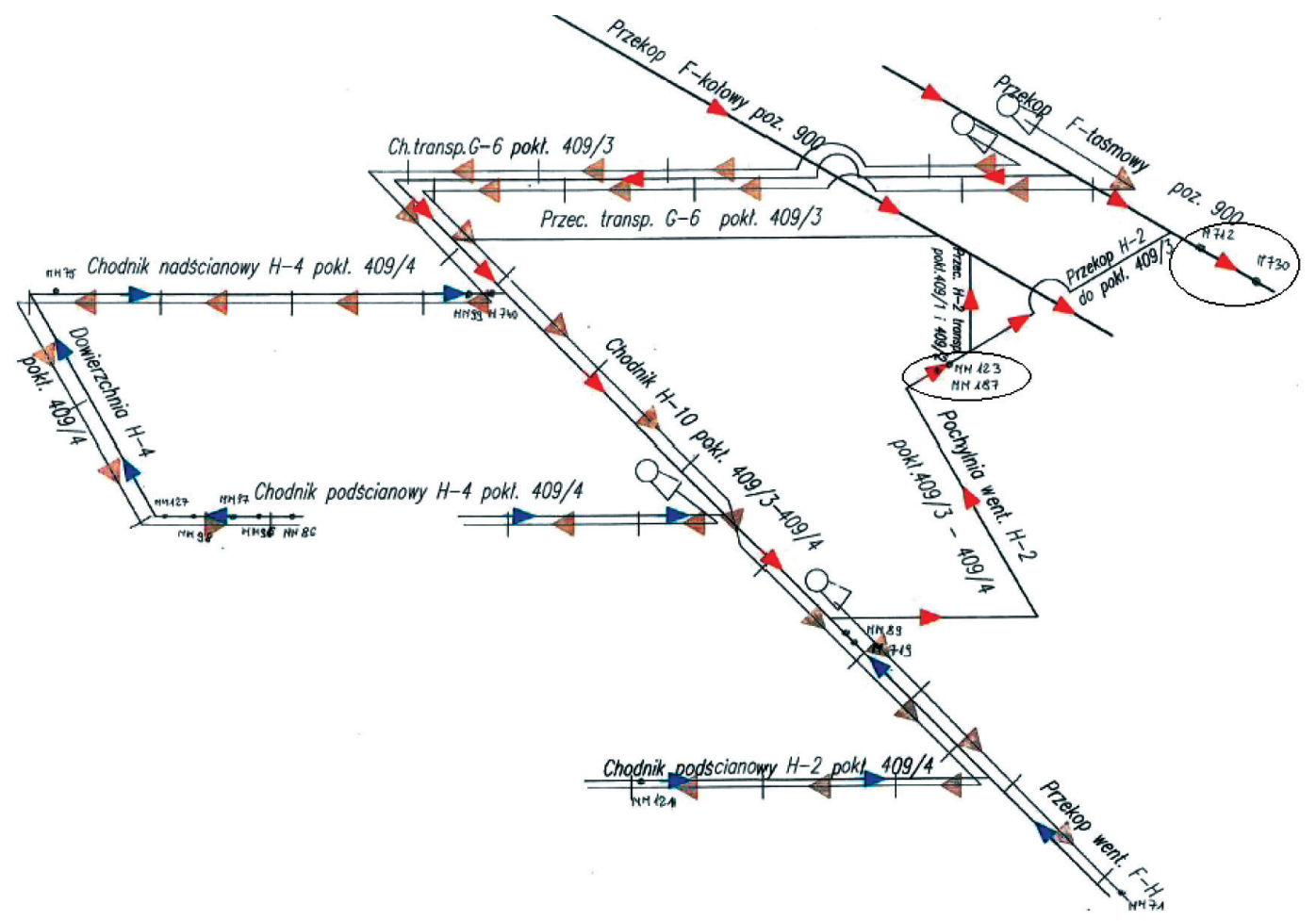

Fig. 3. The ventilation diagram of the H-part of the seam 409/4 with the methane sensors (MM ...) and carbon monoxide sensors (M ...) [11]

a)

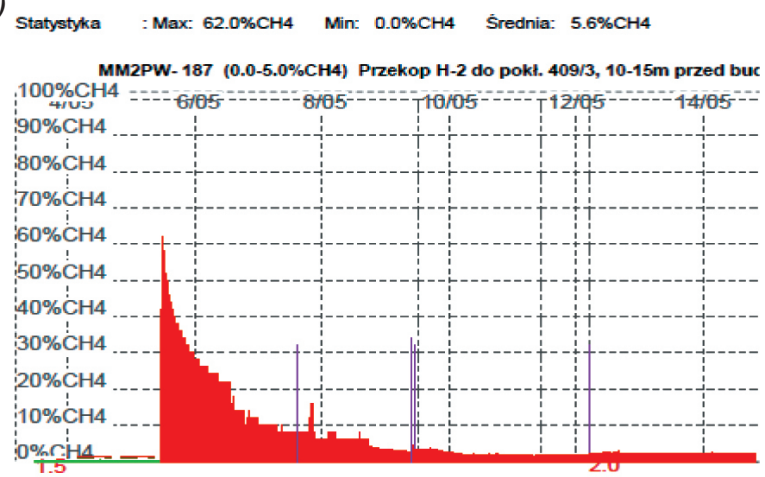

b) Statystyka : Max: $58.0 \% \mathrm{CH} 4 \quad$ Mirn: $0.0 \% \mathrm{CH} 4 \quad$ Średnia: $5.3 \% \mathrm{CH} 4$

MM2PW- 123 (0.0-5.0\%CH4) Przekop H-2 do p.409/3,10-15m przed skrzyż. z prze

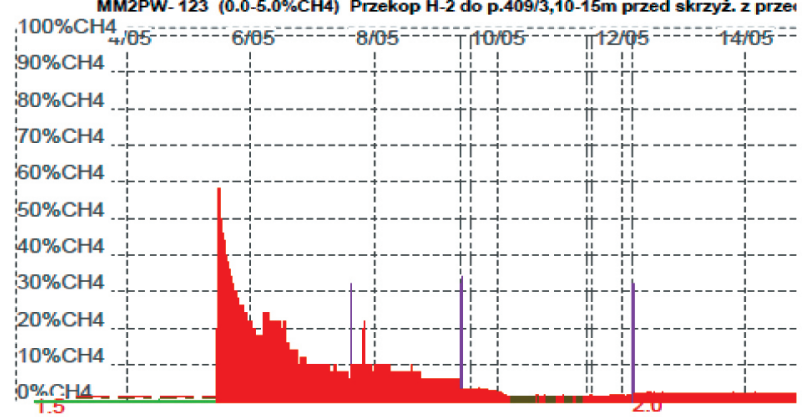

Fig. 4. Indications of the methane detectors before and after the rock burst on 5.05.2018: a) MM187; b) MM123 [11] 


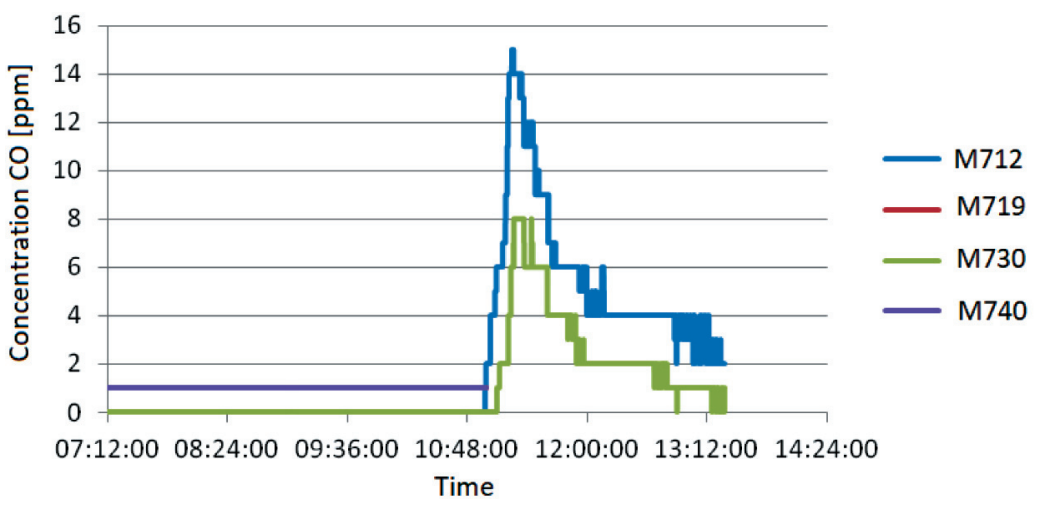

Fig. 5. Indication of carbon monoxide sensors M712 and M730 on 5.05.2018 before and after rock burst [11]

During the work of the commission there were some doubts concerning the reasons for the cause the rock burst, since a blasting operation had been planned at the same time during the development of one of the roadways with the use $7.5 \mathrm{~kg}$ of explosives. The blasting holes had already been filled with explosives and fused with an igniter. It was not possible to confirm if the explosives were not accidentally launched, which would have initiated the rock burst. The special investigation was ordered to explain all the doubts [11].

The analysis of the blasting operations (before the rock burst) conducted in the workings of part $\mathrm{H}$ of seam 409/4 showed that the changes in CO concentrations recorded by the M712 and M730 sensors are characteristic of a rock burst phenomenon, as presented in Figure 6.

Comparing the above changes with the changes after the rock burst (Fig. 5) it can be found that, after the rock burst, the changes in $\mathrm{CO}$ concentration also confirm that the explosives were ignited. However, other facts such as: seismograph records and a statement of the blasting engineer inspecting the face front after the rock burst, did not confirm this. There- fore, it was decided to analyse all CO changes before the rock burst in order, to find other reasons for such an increase in $\mathrm{CO}$ concentrations. It transpired that there was a slight increase in the $\mathrm{CO}$ concentration during the rock burst witch was not provoked by the blasting operation. Only that, the increases in $\mathrm{CO}$ concentration were much lower (Fig. 7). The fact that the energy of these rock bursts was significantly lower than the energy of a rock burst causing a bump was taken to be the starting point for further analyses.

Finding a carbon monoxide source other than blasting with the use of explosives was the next step in the investigation. For that purpose, mining and geological conditions in part $\mathrm{H}$ in all coal seams, taking into account the mining history, were analysed. It emerged that over seam 409/4 there was a mined out (in the main part) seam number 409/3. It was determined that, in gob of the seam, different gases including $\mathrm{CH}_{4}$ and $\mathrm{CO}$ might still be present. Extremely high rock burst energy $-E=2.0 \cdot 10^{9} \mathrm{~J}$ - caused unsealing of the rock mass in part $\mathrm{H}$ and the migration of gases from the gob of seam 409/3 to the workings of seam 409/4 which despite damages caused by a bump were in under pressure generated by the ventilation main fan.

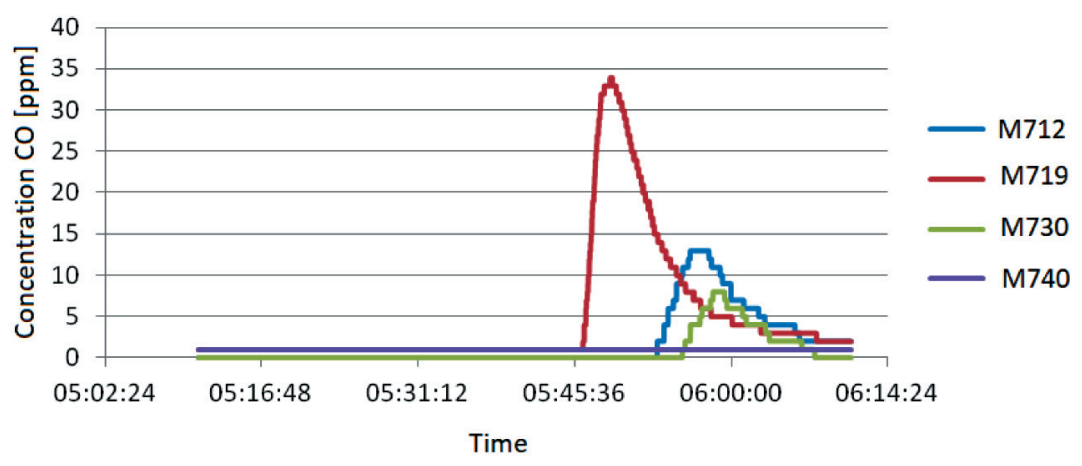

Fig. 6. Example of change in CO concentration on M712 and M730 sensors, relative to M719 and M740 sensors, after blasting operations with use of $7.5 \mathrm{~kg}$ explosives [11] 


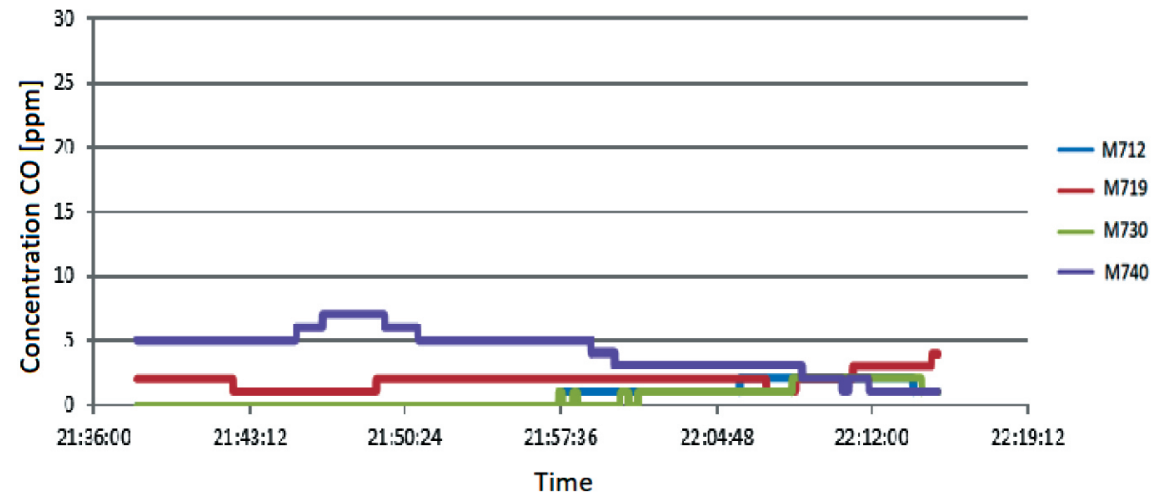

Fig. 7. Changes in CO concentration of individual sensors recorded by each sensor on 25.04.2018 in the H-part after the rock burst at 21:46:26 not related to blasting [11]

This confirmed methane, ethane flow through the area after the bump of volume equal to about $545000 \mathrm{~m}^{3}$ [12], part of which was generated in the seam 409/4 and part from the gob of overlying seam. Also carbon monoxide of maximum concentration $15 \mathrm{ppm}$ and total volume $96 \mathrm{~m}^{3}$, recorded by M712 sensor, entered from the gob. Comparing the characteristics of changes in $\mathrm{CO}$ concentration after the bump (Fig. 6) and the changes shown in models of changes in $\mathrm{CO}$ concentration (Fig. 1) we can see similarity - considering time of changes - with the model describing the changes associated with flowing of carbon monoxide from the gob (Fig. 1a). Thus, a hypothesis that high-energy rock burst was initiated by blasting operation has not been confirmed.

\section{CONCLUSIONS}

The various monitoring systems used in Polish mines, dispatcher systems supporting the taking decisions as well as emergency communication systems are used to assess correctly the level of a given hazard, what allows adjusting the preventive measures to the level of concentration changes and - in the case of significant increase of the hazard level, to automatically notify the crew about danger and the need to leave the threatened area.

Monitoring and alarming systems guarantee reliability of measurement and data transmission, as well as high speed of data processing. Incorrect interpretation of the carbon monoxide source may lead to unnecessary initiation of a rescue actions, generating unreasonable costs. The developed CO source identification subsystem, co-operating with standard monitoring systems, allows quick assessment of the $\mathrm{CO}$ source, eliminating unjustified fire-fighting rescue actions. In a result of a catastrophic event such as methane explosion, coal dust explosion, bumps power supply of the monitoring systems can be broken, so data transmission is interrupted and there is no information available from the region.

In the absence of data from a given region, the assessment of the causes of the event and the state of the current level of threats in such a region cause that the assessment of the current state in such a region must be carried out based on the sensors located outside the given zone.

\section{References}

[1] Trenczek S.: Automatyczna aerometria górnicza dla kontroli zagrożeń aerologicznych. "Mechanizacja i Automatyzacja Górnictwa" 2005, 3: 11-20.

[2] Miśkiewicz K., Wojaczek A.: Telekomunikacja w górnictwie. Systemy tączności telefonicznej, alarmowej i głośnomówiace, Wydawnictwo Politechniki Śląskiej w Gliwicach, Gliwice 2018.

[3] Ustawa z dnia 16 lipca 2004 r. Prawo telekomunikacyjne, Dz.U. z 2004 r., nr 171, poz. 1800 z późn. zm.

[4] Sikora M., Sikora B.: Systemy monitorowania w kopalniach wegla kamiennego - bazy danych, wizualizacja, analiza danych, in: Bazy Danych: Nowe Technologie, red. S. Kozielski et al., Wydawnictwo Politechniki Ślaskiej w Gliwicach, Gliwice 2007.

[5] Wojaczek A.: Telematyka w podziemnych zakładach górniczych, "Mining - Informatics, Automation and Electricalal Engineering" 2017, 7: 27-34.

[6] Cała D., Kozielski M., Sikora B., Sliwa J.: Rozdziat 2. Wybrane systemy monitorowania funkcjonujące $w$ górnictwie węgla kamiennego w Polsce, in: Zintegrowany, szkieletowy system wspomagania decyzji dla systemów monitorowania procesów, urządzeń i zagrożeń, Wydawnictwo Politechniki Śąskiej w Gliwicach, Gliwice 2017.

[7] PN-EN 60079-28:2015-12: Atmosfery wybuchowe - Część 28: Zabezpieczenie urzadzeń oraz systemów transmisji wykorzystujacych promieniowanie optyczne.

[8] Trenczek S.: Przyrost stężenia tlenku węgla w czasie w zależności od źródta jego pochodzenia, "Górnictwo i Geologia" 2014, 8, 3: 159-172.

[9] Dokumentacja etapu 4 pt. "Algorytm identyfikacji przyczyn wzrostu stężenia CO" projektu pt. "Minimalizacja ryzyka występowania i zmniejszenie skutków zagrożenia pożarem i wybuchem w podziemnym górnictwie węglowym MINFIREX” (nr projektu RFCR-CT-2010-00005) realizowanego pod kierownictwem S. Trenczka. Instytut Technik Innowacyjnych EMAG, Katowice 2012 [unpublished]. 
[10] Zarządzenie Nr 41 Prezesa Wyższego Urzędu Górniczego $z$ dnia 7 maja 2018 r. w sprawie powołania Komisji do zbadania przyczyn i okoliczności tapnięcia oraz wypadku zbiorowego, zaistniałych w dniu 5 maja 2018 r. w Jastrzębskiej Spótce Węglowej S.A. KWK "Borynia-Zofiówka-Jastrzębie”, Ruch "Zofiówka” w Jastrzębiu-Zdroju, Dz.Urz. WUG, poz. 100.

[11] Trenczek S.: Analiza wskazań czujników telemetrycznych zabudowanych dla obserwacji aerologicznych i sejsmicznych $w$ rejonie wstrzasu o energii 1,9 x 108 J zaistniatego $w$ dniu 5.05.2018 r. o godzinie 10:58, który spowodowat tapnięcie ze skutkami $w$ wyrobiskach wykonanych w pokładach 409/3 $i$ 409/4 w JSW S.A. KWK "Borynia-Zofiówka-Jastrzębie” Ruch "Zofiówka”, w aspekcie określenia przyczyn zmian ich sekwencji przed i po zaistniabym tapnięciu, przy uwzględnieniu aktywności sejsmicznej, w tym powodowanej robotami strzałowymi. Opracowanie wykonane na zlecenie WUG, 2018 [unpublished].
[12] Szlązak N., Trenczek S.: Analiza zagrożenia metanowego, w kontekście tapnięcia ze skutkami w wyrobiskach wykonanych w pokładach 409/3 i 409/4, zaistniałego w dniu 5.05.2018 r. o godzinie 10:58 w JSW S.A. KWK "Borynia-Zofiówka-Jastrzębie” Ruch "Zofiówka", uwzględniająca stosowane metody prognozowania oraz działalność profilaktyczna. Opracowanie wykonane na zlecenie WUG, 2018 [unpublished].

STANISEAW TRENCZEK, prof. KOMAG Institute of Mining Technology ul. Pszczyńska 37, 44-101 Gliwice, Poland strenczek@komag.eu 


\title{
Wykorzystanie możliwości monitorowania parametrów powietrza przy określaniu źródła tlenku węgla w świetle badań
}

\begin{abstract}
Na wstępie przypomniano istotę systemów monitorowania, oparta na elektronice zapewniającej odpowiednia prędkość $i$ wiarygodność przetwarzania danych pomiarowych, a jednocześnie posiadająca wtaściwe cechy iskrobezpieczeństwa. $W$ dalszej części pokazano przyktady pomiarów stężenia tlenku węgla pochodzącego z różnych źródet. W kontekście zróżnicowanych charakterystyk przebiegu zmian stężenia tlenku węgla odniesiono się do zagadnienia identyfikacji źródła tlenku węgla, którego stężenia pojawity się po wysokoenergetycznym wstrzasie górotworu skutkującym tapnięciem. W celu lepszego zobrazowania zdarzenia przedstawiono uwarunkowania prowadzenia robót górniczych w rejonie objętym skutkami tapnięcia oraz dokonana eksploatację w pokładach nadlegtych tej partii złoża węgla kamiennego. Na koniec przedstawiono wyniki przeprowadzonych badań porównawczych zmian stężenia tlenku węgla oraz wnioski z tego wynikające.
\end{abstract}

Słowa kluczowe: elektronika, systemy monitorowania, źródła tlenku węgla

\section{WPROWADZENIE}

W polskim górnictwie podziemnym średnia głębokość eksploatacji pokładów węgla kamiennego co roku zwiększa się o około $8 \mathrm{~m}$. W związku z tym podczas prowadzenia robót górniczych występują coraz trudniejsze uwarunkowania geologiczno-górnicze. Powoduje to zwykle wzrost poziomu zagrożeń stale towarzyszących górnictwu. Należą do nich zagrożenia pożarowe i wodne, działanie pyłów szkodliwych dla zdrowia, wybuchy pyłu węglowego, jak i coraz częściej występujące zagrożenia: metanowe, tąpania, wyrzuty gazów i skał, wpływ zmian klimatycznych. Im lepsze rozpoznanie tych zagrożeń na etapie projektowania robót górniczych, tym większa możliwość dostosowania działań profilaktycznych w celu zapewnienia bezpieczeństwa prowadzenia robót górniczych. Najważniejsze jest jednak doraźne kontrolowanie parametrów charakteryzujących dane zagrożenie, gdyż pozwala to natychmiastowo reagować na zwiększający się jego poziom.

Aktualnie w polskich kopalniach stosowane są różnego rodzaju systemy monitorowania, dyspozytorskie systemy wspomagające podejmowanie działan, a także systemy łączności alarmowej służące do szybszego, automatycznego powiadamiania załogi o niebezpieczeństwie i konieczności wycofania się z danego rejonu. Należy jednak dodać, że nie wszystkie zagrożenia można - aktualnie - monitorować w sposób ciągły. Jest więc jeszcze wiele do zrobienia w tym zakresie.

W niniejszym artykule zostanie przedstawiony zaledwie wycinek możliwości, jakie w kontroli i ocenie zjawisk aerologicznych daje systemowe monitorowanie. W kontekście zdarzenia, jakie miało miejsce w dniu 5 maja 2018 r., pokazany zostanie przekrój możliwości kontroli stężenia tlenku węgla w powietrzu kopalnianym wraz z możliwościami automatycznej oceny źródła CO.

\section{CHARAKTERYSTYKA SYSTEMOWEGO MONITOROWANIA}

Do kontroli i oceny parametrów powietrza płynącego w podziemnych wyrobiskach górniczych powszechnie stosuje się systemy aerometrii górniczej [1]. Składają się na nią zwykle gazometria automatyczna oraz - 
w przypadku występującego zagrożenia metanowego metanometria automatyczna. Z kolei w przypadku występowania zagrożenia tąpaniami system aerometrii górniczej jest zintegrowany z systemami monitorowania: mikrosejmicznym i sejsmoakustycznym.

$\mathrm{O}$ ile metanometria zawsze pełniła funkcję zabezpieczającą, polegającą na wyłączaniu automatycznym maszyn i urządzeń spod napięcia w rejonach, przez które przepływał prąd powietrza zawierający metan w stężeniu ponadnormatywnym, o tyle stosowanie takich zabezpieczeń w klasycznej gazometrii datuje się dopiero od połowy pierwszego dziesięciolecia XXI wieku. Chodzi tu np. o takie wyłączanie spod napięcia w przypadku spadku prędkości powietrza w rejonie ściany czy przodka $\mathrm{z}$ występującym zagrożeniem metanowym, czy też $\mathrm{w}$ przypadku jednoczesnego otwarcia drzwi w tamach wentylacyjnych stabilizujących kierunek i wydatek powietrza, a także w przypadku zaistniałego w rejonie wstrząsu górotworu o określonej (przez służby kopalniane) energii. Ten ostatni przypadek ma wyeliminować możliwość powstania iskry elektrycznej $\mathrm{w}$ wyniku awarii kabla lub/i urządzenia zasilanego energią elektryczną, która może zainicjować zapłon metanu.

Aby jednak informacje o wartościach mierzonych parametrów mogły być właściwie przetransformowane i wykorzystane, w kopalniach podziemnych niezbędny jest system telekomunikacyjny [2], odpowiedni dla danego rodzaju górnictwa. Przez telekomunikację [3] rozumie się nadawanie, odbiór lub transmisję informacji (jakiejkolwiek natury) za pomocą przewodów, fal radiowych bądź optycznych lub innych środków wykorzystujących energię elektromagnetyczną. Każdy system monitorowania musi gwarantować wiarygodność pomiaru i transmisji danych, charakteryzować się odpowiednio dużą prędkością przetwarzania danych. Istotą przy tym jest możliwość określenia niepewności roboczej przyrządu/czujnika (niepewności w znamionowych warunkach użytkowania), rozdzielczości transmisji, rozdzielczości zapisu wyniku pomiaru w repozytorium i format zapisu $[4,5]$. Ponadto w kopalniach podziemnych, w których występują lub mogą wystąpić zagrożenia wybuchem metanu lub/i pyłu węglowego, system telekomunikacyjny musi spełniać bardziej rygorystyczne wymagania [6]:

- urządzenia dołowe systemów telekomunikacyjnych powinny mieć budowę iskrobezpieczną lub być bezpieczne optycznie (cecha „opis” wg PN-EN 60079-28 [7]) i umożliwiać pracę w warunkach dowolnej koncentracji metanu;
- urządzenia telekomunikacyjne oraz urządzenia współpracujące z tymi systemami stosowane w wyrobiskach powinny mieć stopień ochrony obudowy minimum IP54 - z uwagi na wilgotność, zasolenie i obecność pyłów;

- stosowanie drzewiastej struktury sieci telekomunikacyjnych ze względu na małe poprzeczne wymiary wyrobisk korytarzowych (kilka metrów) w stosunku do ich wymiarów podłużnych (do kilku kilometrów); rozległość wyrobisk.

Istotne jest też zapewnienie możliwie maksymalnej skuteczności rozdziału uziomów elektroenergetycznych (w tym SUPO) i telekomunikacyjnych, przy występującym dużym nagromadzeniu (w ograniczonych przestrzeniach) sieci i urządzeń elektroenergetycznych o bardzo dużych mocach.

Kolejnym istotnym elementem systemów telekomunikacyjnych jest ciągłość zasilania tych urządzeń. O ile typowe, zdarzające się ograniczenia, wynikające z planowych wyłączeń w sieci elektroenergetycznej (np. ze względu na przeprowadzanie napraw), okresowych testowań układów wyłączeń urządzeń elektroenergetycznych realizowanych przez systemy gazometrii, oraz nieplanowe wyłączenia wywołane zadziałaniem zabezpieczeń elektroenergetycznych oraz metanometrycznych, nie stwarzają większych perturbacji w ocenie poziomu zagrożeń, to przerwa w zasilaniu lub/i transmisji danych - np. spowodowana zdarzeniem typu wybuch metanu, wybuch pyłu węglowego, tąpnięcie - powodują kompletny brak informacji z rejonu objętego skutkami danego zdarzenia. Wówczas tylko metodami pośrednimi, bazującymi na danych spoza takiego rejonu można próbować ocenić, co stało się i co dzieje się w danym rejonie.

\section{OCENA ŹRÓDŁA TLENKU WĘGLA NA PODSTAWIE CHARAKTERYSTYKI ZMIAN STEZŻENIA}

W kopalniach węgla kamiennego powszechne jest zagrożenie pożarami endogenicznymi. Występowanie tlenku węgla w powietrzu kopalnianym w stężeniu powyżej 26 ppm lub ilości CO powyżej 25 l/min jest uznawane - jeśli CO nie pochodzi z procesów technologicznych - za pożar, w związku z czym należy wszcząć akcję ratowniczą przeciwpożarową. $\mathrm{Z}$ uwagi na standardowo stosowane sposoby monitorowania zagrożeń aerologicznych mogą się zdarzyć przypadki niewłaściwej interpretacji źródła tlenku węgla, przez 
co może zostać zbytecznie ogłoszona akcja ratownicza przeciwpożarowa, która zawsze pociąga za sobą koszty, a w takim przypadku byłyby one nieuzasadnione.

Ponieważ jest wiele przyczyn, które mogą spowodować pojawienie się $\mathrm{CO}$ w stężeniu lub/i ilościach ponadnormatywnych, ważne jest, by szybko zidentyfikować źródło CO [8]. W celu właśnie takiej szybkiej, automatycznej identyfikacji źródła CO przeprowadzono badania [9] w ramach projektu europejskiego wspótfinansowanego z funduszu Coal \& Steel pt. „Minimalizacja

a)
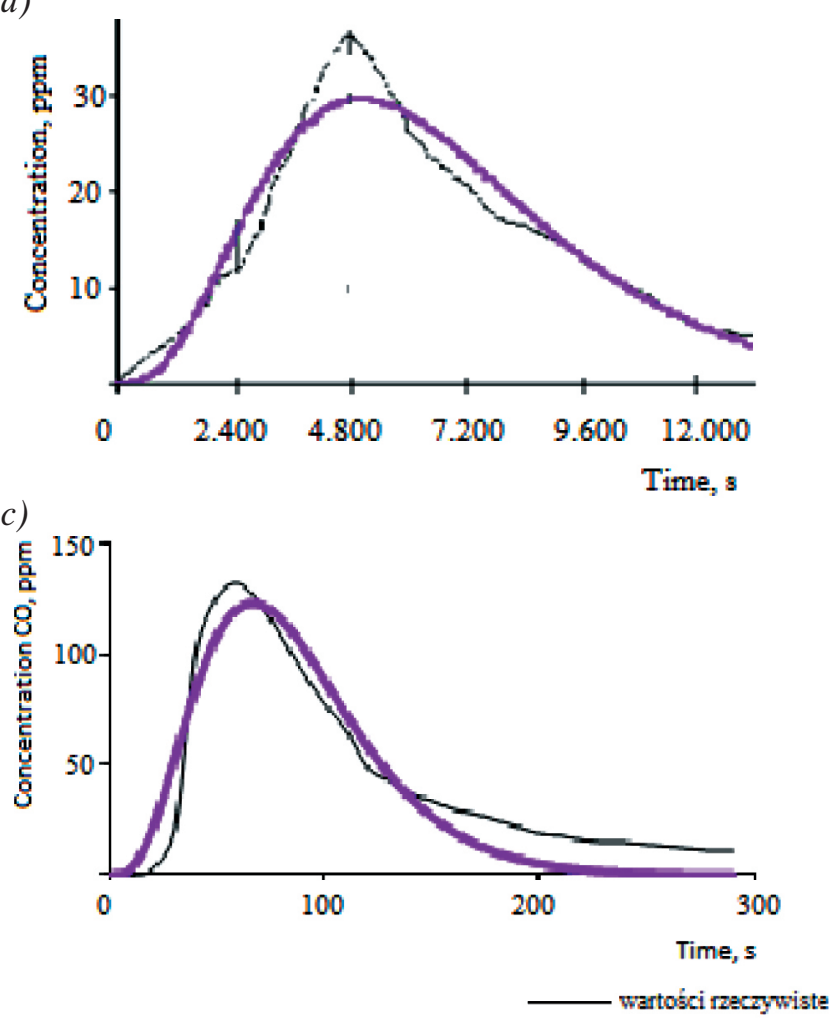

ryzyka występowania i zmniejszenie skutków zagrożenia pożarem i wybuchem w podziemnym górnictwie węglowym". Głównym zadaniem było opracowanie efektywnej detekcji niebezpiecznych atmosfery i gazów pożarowych w celu wyeliminowania błędnej interpretacji powodu wzrostu stężeń CO. Badania pozwoliły na opracowanie modeli zmian stężenia $\mathrm{CO}$ w zależności od źródła jego pochodzenia (rys. 1), oraz opracowanie podsystemu identyfikacji źródeł CO współpracującego ze standardowymi systemami monitorowania.
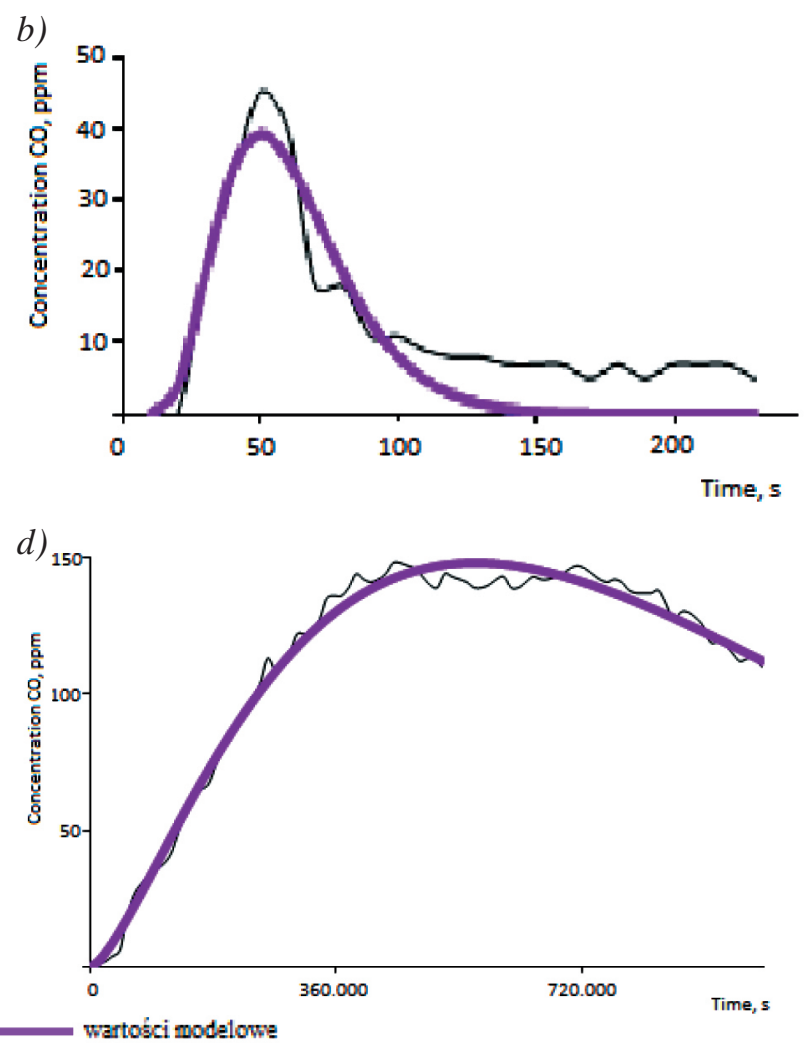

Rys. 1. Modele zmian stężenia CO w zależności od źródta: a) przypadek skutków wyptywu gazów ze zrobów; b) przypadek skutków pracy maszyny spalinowej; c) przypadek skutków robót strzałowych; d) przypadek pożaru endogenicznego [9]

\section{USTALENIE ŹRÓDŁA EMISJI TLENKU WĘGLA W PRZYPADKU WSTRZĄSU GÓROTWORU I POTENCJALNEGO WYKONANIA ROBÓT STRZAŁOWYCH - STUDIUM PRZYPADKU}

W dniu 5 maja 2018 r. o godzinie 10.58 doszło do wysokoenergetycznego wstrząsu górotworu o energii $E=2,0 \cdot 10^{9} \mathrm{~J}$ (początkowa ocena energii wskazywała na wartość $E=1,9 \cdot 10^{8} \mathrm{~J}$ ), który spowodował tąpnięcie (rys. 2). Jego skutki objęły w sumie ok. 820 m odcinków wyrobisk górniczych wykonanych w partii H pokładu 409/4, gdzie łączna długość wykonanych wyrobisk wynosiła ok. 2700 m. W celu wyjaśnienia przyczyn i okoliczności tego tąpnięcia prezes
Wyższego Urzędu Górniczego powołał specjalną komisję [10].

W wyniku tąpnięcia czujniki metanometrii automatycznej oraz czujniki CO-metrii automatycznej zabudowane w tym rejonie przestały działać, gdyż doszło do przerwania zasilania i transmisji danych pomiarowych. Funkcjonowały jedynie czujniki znajdujące się poza rejonem objętym skutkami (rys. 3).

Z działających czujników - czujniki metanu MM187 i MM123 - zarejestrowały znaczacy, dynamiczny przyrost stężenia metanu - rysunek 4 (zapis kolorem czerwonym), po stężeniach dopuszczalnych (kolor zielony). Wzrost stężenia metanu, tyle że o znacznie mniejszej skali (rys. 5), wskazały też czujniki tlenku węgla M712 i M730. 


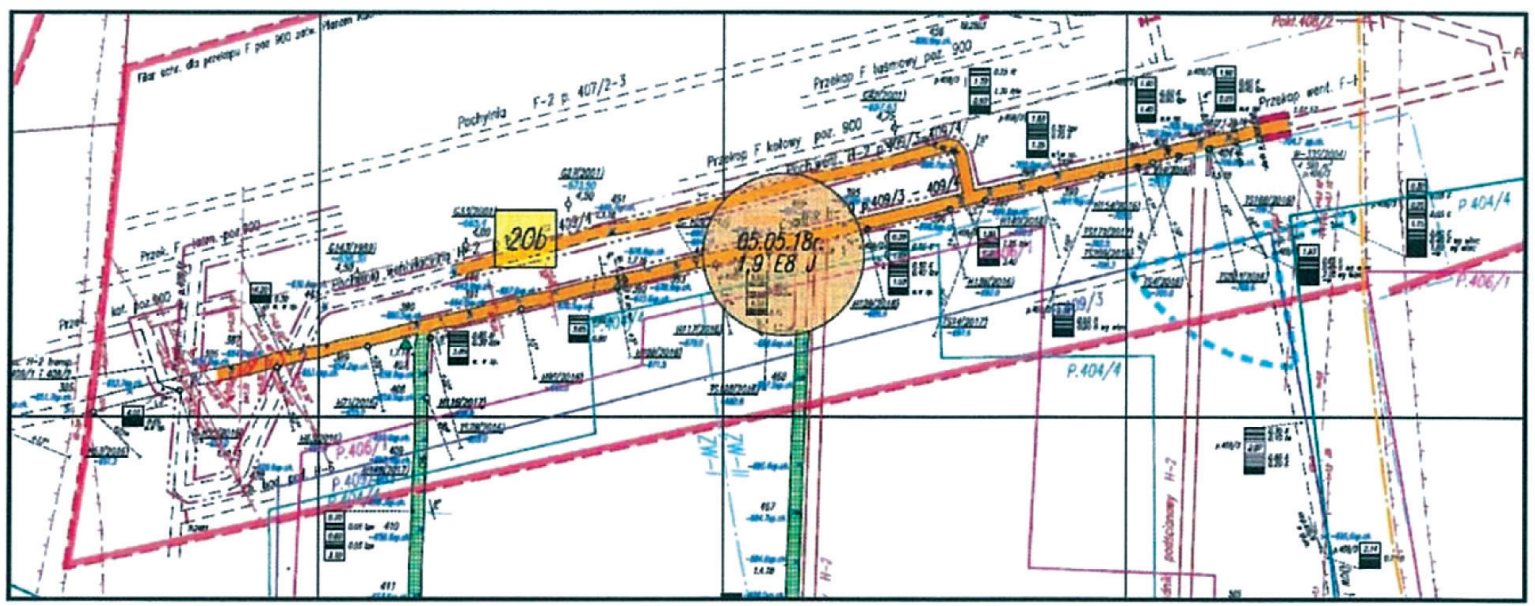

Rys. 2. Fragment mapy wyrobisk górniczych pokładu 409/4 w partii H wraz z lokalizacja wstrząu górotworu [11]

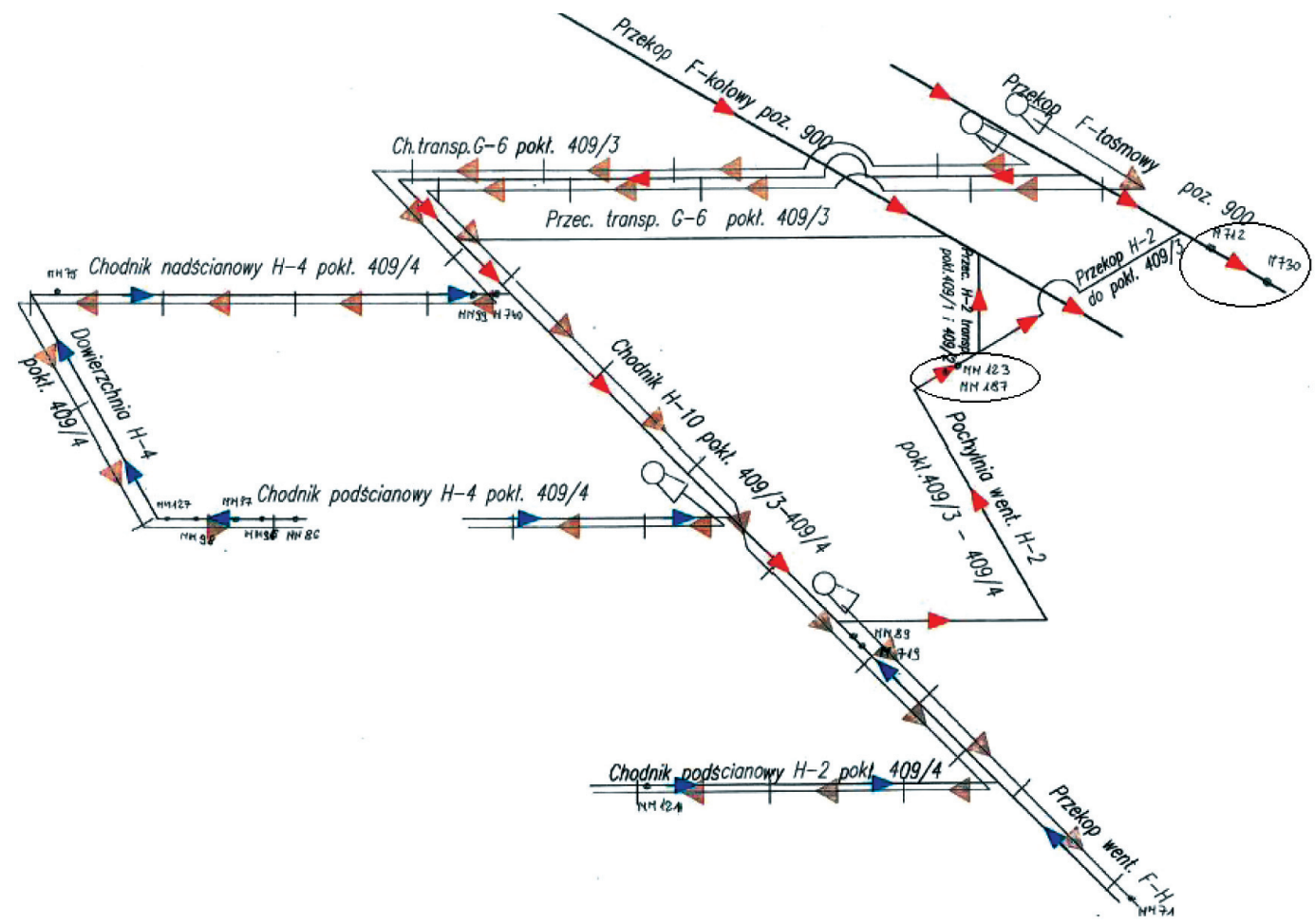

Rys. 3. Schemat wentylacyjny partii H poktadu 409/4 z naniesionymi czujnikami pomiaru metanu (MM...) i tlenku węgla (M...) [11]

a)

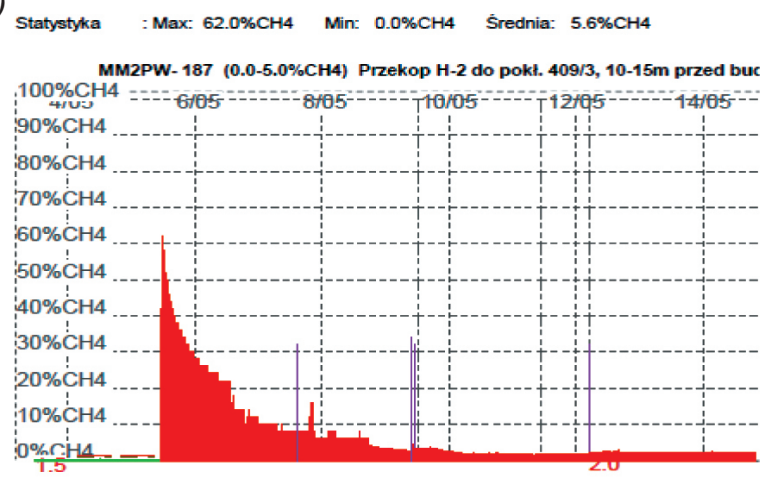

b)

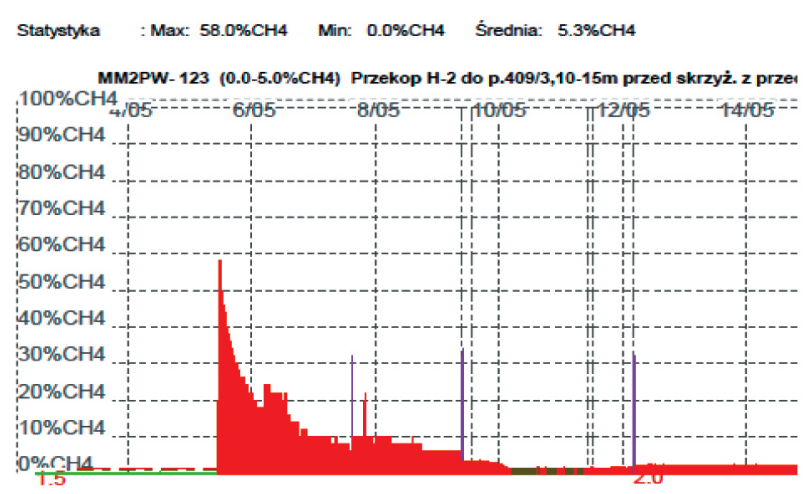

Rys. 4. Wskazania czujników metanu w okresie przed tapnięciem 5.05.2018 r. i po nim: a) MM187; b) MM123 [11] 


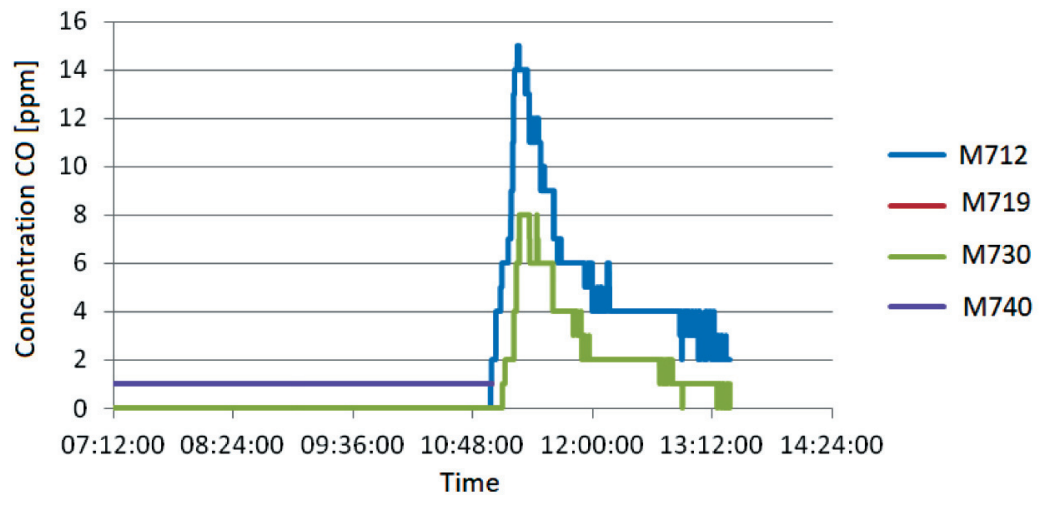

Rys. 5. Wskazania czujników tlenku węgla M712 i M730 5.05.2018 r. przed tapnięciem i po nim [11]

Podczas prac komisji pojawiły się wątpliwości związane z przyczyną, a właściwie inicjacją wstrząsu górotworu, spowodowane tym, że w tym samym czasie, w którym wystąpił wstrząs górotworu i tąpnięcie, w przodku jednego z drążonych wyrobisk korytarzowych miało być wykonane strzelanie urabiające z użyciem 7,5 kg materiału wybuchowego. Doszło już do załadowania otworów strzałowych materiałem wybuchowym i uzbrojenia ich zapalnikami. Nie udało się jednak stwierdzić, czy przypadkiem nie doszło do odpalenia materiału wybuchowego, co mogło być inicjałem wstrząsu górotworu. W celu wyjaśnienia tych wątpliwości zlecono przeprowadzenie stosownych badań [11].

Wykonana w trakcie badań analiza 23 wcześniej (przed tąpnięciem) wykonanych robót strzałowych w drążonych wyrobiskach w partii H pokładu 409/4, które wywołały wstrząsy górotworu, pokazała, że zmiany CO mają charakterystyczny przebieg na czujnikach M712 i M730, co jako przykład ilustruje rysunek 6.

Można by było, po porównaniu go ze zmianami zaistniałymi po tąpnięciu (rys. 5), stwierdzić, że i po tym tąpnięciu zmiany stężenia CO potwierdzają, iż doszło do odpalenia materiału wybuchowego. Jednakże inne fakty - jak m.in. zapis sejsmografu, oświadczenie inżyniera strzelniczego kontrolującego ten przodek po tąpnięciu - nie potwierdzały tej wersji zdarzeń. W związku $\mathrm{z}$ tym prowadzono badania wszystkich zmian stężenia $\mathrm{CO}$ w okresie poprzedzającym tąpnięcie, w celu ewentualnego stwierdzenia innych powodów takich wzrostów. Okazało się, że miały miejsce nieznaczne wzrosty stężenia CO przy wstrząsach górotworu, nieprowokowanych robotami strzałowymi. Tyle że przyrosty stężenia CO były znacznie mniejsze (rys. 7). Fakt, że energia tych wstrząsów była także znacznie mniejsza niż energia wstrząsu powodującego tąpnięcie, można było przyjąć jako punkt wyjścia do dalszych analiz.

Kolejnym krokiem w badaniach było znalezienie źródła tlenku węgla innego niż roboty strzałowe z użyciem materiału wybuchowego. W tym celu przeanalizowano uwarunkowania geologiczno-górnicze w partii $\mathrm{H}$ we wszystkich pokładach węgla wraz z zaszłościami eksploatacyjnymi. Okazało się m.in., że nad pokładem 409/4 zalega wyeksploatowany (w znacznej części) pokład 409/3. Oznaczało to, że w zrobach tego pokładu mogły się znajdować różne gazy, w tym $\mathrm{CH}_{4}$ i $\mathrm{CO}$.

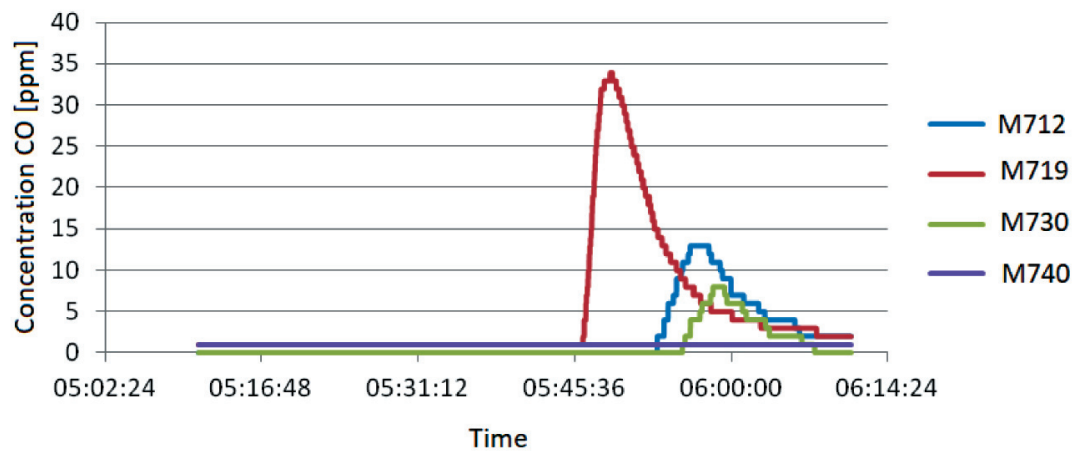

Rys. 6. Przykład zmian stężenia CO na czujnikach M712 i M730 po robotach strzałowych z uzyciem 7,5 kg materiatu wybuchowego [11] 


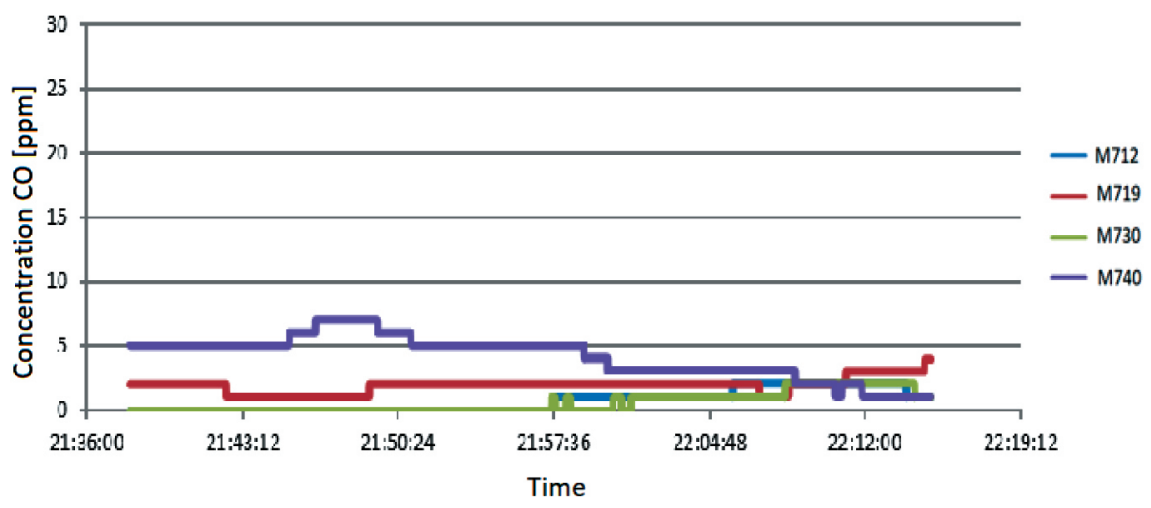

Rys. 7. Zmiany stężeń CO poszczególnych czujników 25.04.2018 r. w rejonie $H$ po wstrzasie zaistnialym o godz. 21.46 .26 bez zwiazku z robotami strzałowymi [11]

Wyjątkowo duża energia wstrząsu $\left(E=2,0 \cdot 10^{9} \mathrm{~J}\right)$ musiała spowodować rozszczelnienie górotworu w partii H i migrację gazów ze zrobów pokładu 409/3 do wyrobisk w pokładzie 409/4, dlatego że wyrobiska te, pomimo częściowego zniszczenia po tąpnięciu, były poddane wpływowi depresji wentylatora głównego przewietrzania.

Potwierdzało to natężenie objętościowe metanu przepływającego przez rejon po tąpnięciu, wynoszące ok. $545000 \mathrm{~m}^{3}$ [12], z którego część została wygenerowana z samego pokładu 409/4, zaś część ze zrobów wyżej zalegającego pokładu. Ze zrobów tych przepłynął także tlenek węgla, zarejestrowany przez czujnik M712 w stężeniu maksymalnym 15 ppm, którego całkowita ilość wynosiła ok. $96 \mathrm{~m}^{3}$ CO. Porównując charakterystykę zmian stężenia $\mathrm{CO}$ po tąpnięciu (rys. 6) do zmian pokazanych na modelach charakterystyk zmian CO (rys. 1), można zauważyć podobieństwo - przy uwzględnieniu czasu zmian - $\mathrm{z}$ modelem obrazującym zmiany związane $\mathrm{z}$ wypływem tlenku węgla ze zrobów (rys. 1a). Zatem hipotezę o inicjacji wysokoenergetycznego wstrząsu górotworu przez wykonanie robót strzałowych można było uznać za niepotwierdzoną.

\section{PODSUMOWANIE}

Stosowane w polskich kopalniach różnego rodzaju systemy monitorowania, dyspozytorskie systemy wspomagające podejmowanie działań, a także systemy łączności alarmowej służą do prawidłowej oceny poziomu danego zagrożenia, co pozwala na dostosowanie działań profilaktycznych do zmieniającego się poziomu, a także w przypadku zdecydowanego, ponadnormatywnego wzrostu poziomu zagrożenia, do automatycznego powiadamiania załogi o niebez- pieczeństwie i konieczności wycofania się z danego rejonu.

Systemy monitorująco-alarmujące charakteryzują się gwarantowaną wiarygodnością pomiaru i transmisji danych, a także dużą prędkością przetwarzania danych.

Przypadki niewłaściwej interpretacji źródła tlenku węgla pokazują, że może dojść do nieuzasadnionego wszczęcia akcji ratowniczej, co pociąga za sobą zbędne koszty.

Opracowany podsystem identyfikacji źródeł CO, współpracujący ze standardowymi systemami monitorowania, pozwala na szybką ocenę źródła CO, przez co eliminuje się przypadki nieuzasadnionego wszczynania akcji ratowniczej przeciwpożarowej.

W przypadkach szczególnych, np. w wyniku katastrofy - wybuchu metanu, wybuchu pyłu węglowego, tąpnięcia - dochodzi do przerwania zasilania systemów monitorowania, przerwania linii transmisji danych pomiarowych, przez co występuje totalny brak danych pomiarowych $\mathrm{z}$ rejonu.

W przypadku braku danych pomiarowych $\mathrm{z}$ danego rejonu ocena przyczyn zdarzenia, jak i stanu aktualnego poziomu zagrożeń $\mathrm{w}$ takim rejonie przeprowadzona być musi na podstawie wskazań czujników zabudowanych poza danym rejonem.

\section{Literatura}

[1] Trenczek S.: Automatyczna aerometria górnicza dla kontroli zagrożeń aerologicznych, „Mechanizacja i Automatyzacja Górnictwa" 2005, 3: 11-20.

[2] Miśkiewicz K., Wojaczek A.: Telekomunikacja $w$ górnictwie. Systemy łączności telefonicznej, alarmowej i głośnomówiące, Wydawnictwo Politechniki Śląskiej, Gliwice 2018.

[3] Ustawa z dnia 16 lipca 2004 r. Prawo telekomunikacyjne, Dz.U. z 2004 r. Nr 171, poz. 1800 z późn. zm.

[4] Sikora M., Sikora B.: Systemy monitorowania $w$ kopalniach węgla kamiennego - bazy danych, wizualizacja, analiza danych, w: Bazy Danych: Nowe Technologie, red. S. Kozielski et al., Wydawnictwo Politechniki Śląskiej, Gliwice 2007. 
[5] Wojaczek A.: Telematyka w podziemnych zakładach górniczych, „Mining - Informatics, Automation and Electricalal Engineering" 2017, 7: 27-34.

[6] Cała D., Kozielski M., Sikora B., Śliwa J.: Zintegrowany, szkieletowy system wspomagania decyzji dla systemów monitorowania procesów, urządzeń i zagrożeń, Wydawnictwo Politechniki Śląskiej, Gliwice 2017.

[7] PN-EN 60079-28:2015-12: Atmosfery wybuchowe - Część 28: Zabezpieczenie urzadzeń oraz systemów transmisji wykorzystujacych promieniowanie optyczne.

[8] Trenczek S.: Przyrost stężenia tlenku węgla w czasie w zależności od źródta jego pochodzenia, „Górnictwo i Geologia” 2014, 8, 3: 159-172.

[9] Dokumentacja etapu 4 pt. „Algorytm identyfikacji przyczyn wzrostu stężenia CO” projektu pt. „Minimalizacja ryzyka występowania i zmniejszenie skutków zagrożenia pożarem i wybuchem w podziemnym górnictwie węglowym - MINFIREX" (nr projektu RFCR-CT-2010-00005) realizowanego pod kierownictwem S. Trenczka. Instytut Technik Innowacyjnych EMAG, Katowice 2012 [praca niepublikowana].

[10] Zarzadzenie nr 41 Prezesa Wyższego Urzędu Górniczego z dnia 7 maja 2018 r. w sprawie powotania Komisji do zbadania przyczyn i okoliczności tapnięcia oraz wypadku zbiorowego, zaistniatych w dniu 5 maja 2018 r. w Jastrzębskiej Spótce Węglowej S.A. KWK „Borynia-Zofiówka-Jastrzębie”, Ruch „Zofiówka” w Jastrzębiu-Zdroju, Dz.Urz. WUG, poz. 100.
[11] Trenczek S.: Analiza wskazań czujników telemetrycznych zabudowanych dla obserwacji aerologicznych $i$ sejsmicznych $w$ rejonie wstrzasu o energii $1,9 \times 108 \mathrm{~J}$ zaistniatego $w$ dniu 5.05.2018 r. o godzinie 10:58, który spowodowat tapnięcie ze skutkami w wyrobiskach wykonanych w poktadach 409/3 i 409/4 w JSW S.A. KWK „Borynia-Zofiówka-Jastrzębie” Ruch „Zofiówka”, w aspekcie określenia przyczyn zmian ich sekwencji przed i po zaistniatym tapnięciu, przy uwzględnieniu aktywności sejsmicznej, w tym powodowanej robotami strzatowymi. Opracowanie wykonane na zlecenie WUG, 2018 [praca niepublikowana].

[12] Szlązak N., Trenczek S.: Analiza zagrożenia metanowego, w kontekście tapnięcia ze skutkami w wyrobiskach wykonanych $w$ pokładach 409/3 $i$ 409/4, zaistniatego $w$ dniu 5.05.2018 $r$ o godzinie 10:58 w JSW S.A. KWK „Borynia-Zofiówka-Jastrzębie” Ruch „Zofiówka”, uwzględniająca stosowane metody prognozowania oraz działalność profilaktyczna. Opracowanie wykonane na zlecenie WUG, 2018 [praca niepublikowana].

dr hab. inż. STANISEAW TRENCZEK, prof. $K O M A G$

Instytut Techniki Górniczej KOMAG ul. Pszczyńska 37, 44-101 Gliwice strenczek@komag.eu 